Far Eastern Federal University Russian Geographical Society

\title{
SHORE RESEARCH \\ IN PACIFIC RUSSIA
}

Collection of Scientific Articles

Edited by a professor P.F. Brovko

Vladivostok

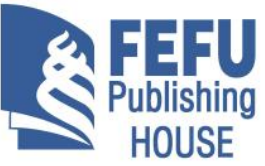

2020 
Дальневосточный федеральный университет

Русское географическое общество

175-летию

Русского географического

общества посвящается

\section{БЕРЕГОВЫЕ ИССЛЕДОВАНИЯ В ТИХООКЕАНСКОЙ РОССИИ}

Сборник научных статей

Под научной редакичей

профессора П.Ф. Бровко

Владивосток

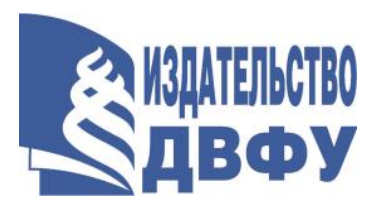

2020 
UDC 504.62(210.5)(571.6)(082)

LBC 26.221.88(255)я43

S55

Editorial board:

P.F. Brovko, ScD in Geography (chief editor);

M.G. Zhukovina (secretary of the editorial board);

A.O. Gorbunov, $\mathrm{PhD}$; A.V. Malyugin;

Yu.A. Mikishin, PhD; A.M. Sazykin, PhD.

Shore research in Pacific Russia : Collection of Scientific S55 Articles / under the scientific editorship P.F. Brovko ; editorial board: P.F. Brovko (chief editor), M.G. Zhukovina (secretary of the editorial board), A.O. Gorbunov, A.V. Malyugin, Yu.A. Mikishin, A.M. Sazykin. - Vladivostok: Publishing House of the Far Eastern Federal University, 2020. - 315 p. : il.

ISBN 978-5-7444-4825-7.

DOI dx.doi.org/10.24866/7444-4825-7.

A collection of scientific articles has been prepared for the 40th anniversary of the Coast Studies section of the Society for the Study of the Amur Region (Russian Geographical Society). The works are devoted to one of the main problems of coastal research: questions of theory and methodology of coastal research; current state and dynamics; natural resources of the coastal zone; problems of environmental management.

The collection is addressed to geographers, ecologists, economists, specialists in nature conservation and integrated coastal zone management. It will be useful to students, undergraduates and postgraduates of geographical specialties.

UDC 504.62(210.5)(571.6)(082)

LBC 26.221.88(255)я43 
П.Ф. Бровко, д-р геогр. наук (председатель);

М.Г. Жуковина (секретарь);

А.О. Горбунов, канд. геогр. наук;

А.В. Малюгин; Ю.А. Микишин, канд. геогр. наук;

А.М. Сазыкин, канд. геогр. наук.

На 1-й и 4-й страницах обложки: «Каменная сказка Сахалина» фото Андрея Сучкова (г. Холмск, Сахалинская область).

На 2-й и 3-й страницах обложки: «Белые скалы Итурупа» фото Владимира Дейкина (г. Долинск, Сахалинская обл.)

Береговые исследования в Тихоокеанской России :

Б48 сборник научных статей / под науч. ред. П.Ф. Бровко ; ред. кол.: П.Ф. Бровко (председатель), М.Г. Жуковина (секретарь), А.О. Горбунов, А.В. Малюгин, Ю.А. Микишин, А.М. Сазыкин. - Владивосток : Издательство Дальневосточного федерального университета, 2020. - 315 с. : ил.

ISBN 978-5-7444-4825-7.

DOI dx.doi.org/10.24866/7444-4825-7.

Сборник научных статей подготовлен к 40-летию секции береговедения Приморского краевого отделения Русского географического общества - Общества изучения Амурского края. Работы посвящены некоторым важным проблемам изучения берегов. Среди них: вопросы теории и методологии исследования берегов; современное состояние и динамика; ресурсы прибрежной зоны; проблемы рационального природопользования.

Сборник адресован географам, экологам, экономистам, специалистам по охране природы и комплексному управлению прибрежной зоной. Будет полезен студентам, магистрантам и аспирантам географических специальностей.

УДК 504.62(210.5)(571.6)(082)

ББК 26.221.88(255)я43 


\section{СОДЕРЖАНИЕ}

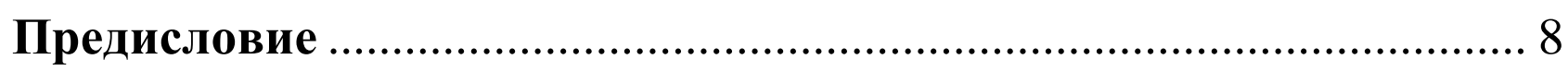

ИЗ ИСТОРИИ БЕРЕГОВЫХ ИССЛЕДОВАНИЙ .......................... 9

Бровко П.Ф. Дальневосточная научная школа

комплексного береговедения …….................................................. 9

Завражнова Е.А. Геоморфология побережья Приморья

в трудах В.К. Арсеньева ………………………….......................... 28

Никонорова И.В., Гуменюк А.Е. Научное и методическое

наследие профессора Е.И. Арчикова................................................... 35

\section{ТЕОРЕТИЧЕСКИЕ И ПРИКЛАДНЫЕ АСПЕКТЫ}

БЕРЕГОВЕДЕНИЯ

Бровко П.Ф., Мануйлов В.А. О литологии и рельефе подводных

береговых склонов островов западной части Индийского океана .. 43

Горин С.Л. Многолетняя динамика аккумулятивных барьерных форм на берегах Камчатки

Горбунов А.О. Р Разрушение западного берега перешейка

Поясок острова Сахалин (по данным натурных наблюдений) ........ 67

Давыдов А.В. Общая характеристика береговой системы

«Крылатый мыс» полуострова Горький Кут, Черное море

Коротаев В.Н. Морфогенетические типы устьевых систем

Камчатки.

Лебедев А.М., Егидарев Е.Г., Пьянов А.А., Жариков В.В., Югай И.Г.

Исследование донных ландшафтов архипелага Катба

(Тонкинский залив, Южно-Китайское море) .................................... 96

Леонова Т.Д., Белоус О.В. Тенденции развития берегов

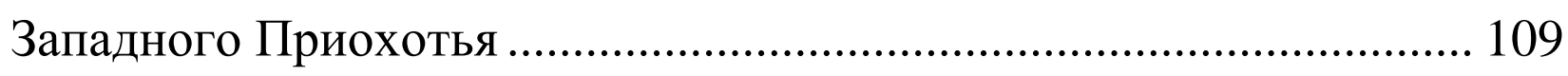

Мануйлов В.А., Петренко В.С. Литология и подводные

ландшафты бухты Витязь (залив Петра Великого) 
Микишин Ю.А. Позднеатлантическая трансгрессия Охотского моря на побережье Юго-Восточного Сахалина................................. 131 Петренко В.С. Формирование и современное состояние берегов Приморья ………………………………………………...... 144 Хомчановский А.Л. Моделирование береговых процессов............... 156 Храмушин В.Н. Вычислительная модель очага морских наводнений от сейсмических и атмосферных возмущений ............ 173 ПРИБРЕЖНО-МОРСКОЕ ПРИРОДОПОЛЬЗОВАНИЕ ............ 187 Бровко П.Ф., Меньчик А.А., Дзен Г.Н., Первухин С.М. Кекуры береговой зоны Сахалина как объекты туризма

Васина М.B. Топонимия водопадов прибрежных регионов Дальнего Востока

Жуковина М.Г. Проблемы развития комплексного управления

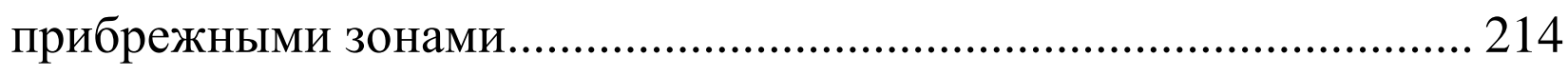
Котляров Д.А. Памятники природы северного побережья Охотского моря

Лебедев И.И. Палеогеографический анализ проявления цунами в бухтах Приморья для целей рекреационного природопользования 240 Преловский В.И., Виговская В.Н., Сойников А.С. Геосистемная комплексная оценка градостроительных и рекреационных ресурсов островных территорий города Владивостока ................... 250

\section{ХРОНИКА, СОБЫТИЯ ………………………........................... 274}

Андреева М.Ю., Горбунов А.О. III Всероссийская научная конференция с международным участием «Геодинамические процессы и природные катастрофы» ............................................... 274 Васина М.В. Круглые столы по береговой тематике на конференциях Тихоокеанского института географии ДВО РАН 283 
Жуковина М.Г. О 26-й Международной конференции PACON-2019 «Морские науки и технологии для устойчивого развития»

Хомчановский А.Л. Международная береговая конференция «Арктические берега: путь к устойчивости» 293

РЕЦЕНЗИЯ 299

Бровко П.Ф. «История развития и методология береговедения»значительный вклад в науку о морских берегах 299 
Научное издание

\section{БЕРЕГОВЫЕ ИССЛЕДОВАНИЯ} В ТИХООКЕАНСКОЙ РОССИИ

Сборник научных статей

Компьютерная верстка М.Г. Жуковиной 
Подписано в печать 10.06.2020 г.

Формат 60×84 / 16. Усл. печ. л. 18,31.

Тираж 500 экз. (1-й завод 1-100). Заказ 18-06.

Дальневосточный федеральный университет 690091, г. Владивосток, ул. Суханова, 8

Отпечатано в Дальневосточном федеральном университете 690091, г. Владивосток, ул. Суханова, 8 (Типография Издательства ДВФУ, 690091, г. Владивосток, ул. Пушкинская, 10) 